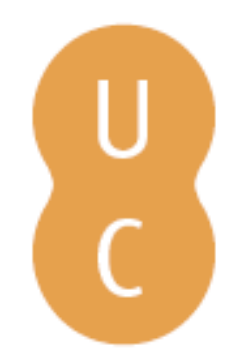

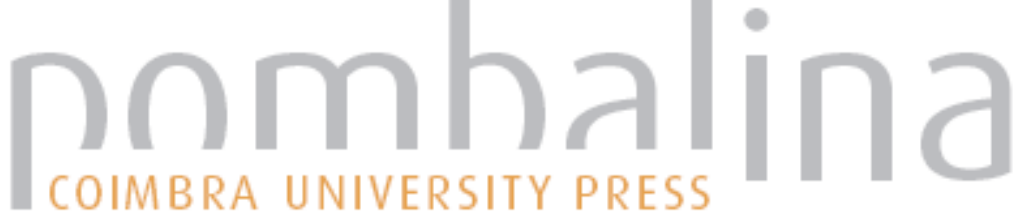

\section{Interpretando o conjunto dos achados}
Autor(es):
Lima, Tania Andrade

Publicado por: Imprensa da Universidade de Coimbra

URL persistente:

URI:http://hdl.handle.net/10316.2/45257

DOI:

DOI:https://doi.org/10.14195/978-989-26-1720-6_17

Accessed : $\quad$ 26-Apr-2023 08:37:36

A navegação consulta e descarregamento dos títulos inseridos nas Bibliotecas Digitais UC Digitalis, UC Pombalina e UC Impactum, pressupõem a aceitação plena e sem reservas dos Termos e Condições de Uso destas Bibliotecas Digitais, disponíveis em https://digitalis.uc.pt/pt-pt/termos.

Conforme exposto nos referidos Termos e Condições de Uso, o descarregamento de títulos de acesso restrito requer uma licença válida de autorização devendo o utilizador aceder ao(s) documento(s) a partir de um endereço de IP da instituição detentora da supramencionada licença.

Ao utilizador é apenas permitido o descarregamento para uso pessoal, pelo que o emprego do(s) título(s) descarregado(s) para outro fim, designadamente comercial, carece de autorização do respetivo autor ou editor da obra.

Na medida em que todas as obras da UC Digitalis se encontram protegidas pelo Código do Direito de Autor e Direitos Conexos e demais legislação aplicável, toda a cópia, parcial ou total, deste documento, nos casos em que é legalmente admitida, deverá conter ou fazer-se acompanhar por este aviso. 
Carmen Soares

\section{Cilene da Silva Gomes Ribeiro}

\section{(coords.)}

MESAS

\section{ALIMENTAÇÃ O, SAÚDE \& CULTURA}

\section{IU LUO-BRASILEIRAS}

\section{VOLUME II}

IMPRENSA DA UNIVERSIDADE DE COIMBRA

COIMBRA UNIVERSITY PRESS

PUCPRESS 


\title{
INTERPRETANDO O CONJUNTO DOS ACHADOS
}

\author{
(Interpreting the findings)
}

\author{
Tania Andrade Lima \\ Museu Nacional / Universidade Federal do Rio de Janeiro \\ TALIMA8@GMAIL.COM
}

As escavações arqueológicas empreendidas no terreno da Rua da Assembleia recuperaram um poço em torno do qual se aglomeravam escravos urbanos, os chamados aguadeiros, que, com seus barrís, abasteciam de água a população das imediações. Este era um dos seus principais encargos na área urbana, juntamente com a coleta e despejo de lixo, trazido das vizinhanças e descarregado nas imediações do poço. O depósito de dejetos que aí foi acumulado pode ser considerado como bastante representativo da sociedade seiscentista e setecentista do Rio de Janeiro. O então centro da cidade era povoado por aristocratas, grandes negociantes, altas e baixas patentes militares, altos e baixos funcionários da burocracia civil, membros da hierarquia do clero, pequenos comerciantes, oficiais mecânicos, artesãos, aventureiros, traficantes de escravos, indígenas, africanos escravizados, entre outros, de tal forma que a cultura material recuperada no terreno pode ser atribuída a diferentes segmentos étnicos e a estamentos sociais muito distintos. Neste último caso, desde os mais abastados, passando pelos que tinham capacidade limitada de aquisição, e, por conseguinte, de escolha, até os que a tinham pouca ou nenhuma.

Foi possível recuperar nesse microcosmo a totalidade dos elementos que compõem um sistema alimentar. Feita a escolha, os gêneros podiam ser obtidos em armazém de secos e molhados nas proximidades, cujos contêineres e medidas foram encontrados; as carnes, no matadouro e no açougue que ficava nas vizinhanças do terreno. $\mathrm{O}$ processamento das comidas, feito nas panelas de barro, e sua apresentação à mesa e consumo nas travessas e pratos de louça, respectivamente; e, por fim, o local onde os restos dessas atividades eram descartados.

$\mathrm{Na}$ análise dos restos faunísticos, dada a dimensão da amostra, apresentamos aqui apenas as cabeças de boi que entendemos terem sido consumidas pelos escravizados. Mas foram encontrados, particularmente dos bovinos, tanto cortes de carne macia, de custo elevado, quanto cortes de carne dura e/ ou nervuda, mais acessíveis, porém passiveis de serem processadas apenas em meio líquido. Subprodutos alimentares dos distintos segmentos mencionados acima, esses restos constituem uma amostra expressiva da sua diversidade e de suas possibilidades de escolha em relação àquele que constituía o elemento mais importante da dieta da população à época, a carne bovina, tal como 
amplamente atestado pela sua elevada frequência no registro arqueológico, muito maior que a de ovinos e suínos, aves e peixes.

As louças recuperadas, em grande maioria faianças portuguesas em decorrência das práticas monopolistas da metrópole, apresentaram formas predominantemente fundas, que remetem a uma culinária rica em sopas, caldos, guisados e ensopados, nos quais os cortes de carne dura encontrados desempenhavam um papel fundamental na sua elaboração. Essas faianças, ao que indicam os muitos achados feitos pela arqueologia, estiveram maciçamente presentes em grande parte das mesas brasileiras nesse período. Já as porcelanas orientais e as faianças de outros centros produtores europeus, no caso, Itália, Holanda e Espanha, foram privilégio de apenas alguns, em vista de seu preço elevado. Nessas últimas predominam os pratos rasos, ao contrário do que se observa nas formas da faiança de Portugal, o que decerto tem relação com o perfil das suas respectivas dietas, distintas da portuguesa.

Quanto aos recipientes utilizados no preparo e armazenagem dos alimentos, foi constatada a presença inesperada de elementos formais e decorativos portugueses nos que foram encontrados no sítio, em diferentes categorias funcionais. Pouco frequentes em outros contextos brasileiros, esses elementos sinalizam que a influência portuguesa parece ter sido maior nos centros urbanos que tinham conexão direta com a metrópole, e onde o trânsito e a presença de portugueses eram mais expressivos. O fato de seus referenciais terem penetrado nas cozinhas, espaços sob forte influência africana, demonstra que, não obstante se tratar de locais de trabalho de mulheres escravizadas, o sistema alimentar dos eurodescendentes estava, a essa época, sob seu controle direto, porquanto mais identificado com o gosto português. Mesmo assim, o equipamento por elas utilizado nas cozinhas manteve alguns referenciais africanos. Expresssões híbridas, portanto, características de um universo multicultural, essas cerâmicas resultaram da coexistência de pessoas muito distintas entre si, que nelas expressaram suas diferenças.

Assim, foi preservado no solo do terreno da Rua da Assembleia um conjunto de evidências que atestam, especialmente no sistema alimentar, influências muito diversas. Essas influências levaram a novas expressões e formulações no equipamento material, que, por sua vez, estavam correlacionadas a novos modos de processar, fazer, utilizar e ingerir, em um universo marcado pelo encontro e confronto de diferenças étnicas, sociais, econômicas e culturais.

Tendo em mãos esses resultados para o século XVIII, foi nosso objetivo investigar a seguinte questão: a súbita transferência da capital do Império Português para o Rio de Janeiro, em 1808, provocou uma transformação radical na cidade pequena e acanhada, totalmente despreparada para receber a Família Real e sua numerosa comitiva. A vida cotidiana, no que diz respeito às rotinas diárias e formas de comportamento, sofreu um forte abalo, tornando imperiosa a necessidade da sua reordenação, de modo a suprir as novas necessidades 
que se impunham. Somada ao rompimento do pacto colonial, ela determinou profundas mudanças e inovações em diferentes níveis, que se estenderam ao longo da primeira metade do século XIX. Indagamos, no caso, se o domínio das práticas alimentares - um dos mais conservadores da cultura e um dos que mais resiste a transformações - se deixou permear por essas mudanças, ou se manteve seu apego à tradição setecentista, razão pela qual apresentamos a seguir os resultados obtidos para a primeira metade do século XIX. 
(Página deixada propositadamente em branco) 